\title{
Diagnosis dan tatalaksana pasien karsinoma sel renal
}

\author{
Ni Made Dwi Adnyani' ${ }^{1}$ I Gde Raka Widiana²
}

${ }^{1}$ Dokter Residen PPDS-1 Program Studi Penyakit Dalam FK Unud/RSUP Sanglah ${ }^{2}$ Divisi Ginjal Hipertensi, Departemen/ KSM IImu Penyakit Dalam FK Unud/ RSUP Sanglah adnyanidwi270687@gmail.com
Tanggal diterima : 8 Juni 2018 Tanggal Disetujui : 5 Juli 2018 Tanggal Diterbitkan : 12 Juli 2018
Karsinoma sel renal (KSR) merupakan kanker yang cukup sering terjadi, sekitar 3 sampai 4\% kasus di Amerika Serikat, namun di Asia kasusnya cukup jarang. Insiden KSR semakin menigkat dalam beberapa tahun terakhir. Perokok aktif dan pasif seperti juga hipertensi merupakan faktor risiko KSR. Dilaporkan sebuah kasus, perempuan, 61 tahun, dengan Chronic Kidney Disease (CKD) stadium V et causa chronic pyelonephritis (PNC) single kidney, batu ureter 1/3 distal sinistra, hidronefrosis derajat IV ginjal sinistra, adenokarsinoma (Adeno (a) renal dextra stadium III post radical nefrectomy. Pasca operasi kondisi pasien sempat membaik, produksi urine cukup $\pm 800 \mathrm{cc} / 24$ jam, dan ada penurunan serum kreatinin. Pasien sempat menjalani beberapa kali hemodialis selama perawatan dan direncanakan hemodialisis regular. Sepuluh hari paska MRS pasien kembali dirawat dengan pneumonia (Health Care Associated Pneumonia) dan diberikan antibiotik empiris, dalam perkembanganya kondisi semakin memburuk dan akhirnya meninggal dengan penyebab kematian syok sepsis. Kasus ini diangkat untuk memperdalam mengenai diagnosis dan tatalaksana seorang penderita dengan renal sel karsinoma sehingga dapat mencegah terjadinya prognosis buruk di kemudian hari.

Kata Kunci : KSR, nefrectomy, diagnosis, tata laksana

Renal Cell Carcinoma (RCC) is the highest prevalence of cancer, its about 3-4\% in United States of America, but in Asia the case is very rared. Actually in more year the incidence of this cancer is quite high. Active smoker and hypertension people is the most risk factor to developed RCC. This is a case, female, 61 years old, with Chronic Kidney Disease (CKD) stadium V et causa chronic pyelonephritis (PNC) single kidney, ureter stone 1/3 distal sinistra, hidronefrosis derajat IV renal sinistra, adenokarsinoma (Adeno (a) renal dextra stadium III post radical nefrectomy. After operation, patient is recovery well, the urine production was $\pm 800 \mathrm{cc} / 24$ hours, and there is decreasing of creatinin serum. The patient had several times to undergo hemodialis during treatment and planned regular hemodialysis. Ten days after the MRS the patient was again treated with pneumonia (Health Care Associated Pneumonia) and given empirical antibiotics, in its development the condition worsened and eventually died with the cause of death of septic shock. This case was raised to deepen the diagnosis and management of a patient with carcinoma renal cells so that it can prevent a bad prognosis in the future.

Keywords : RCC, nefrectomy, diagnosis, theraphy

\section{PENDAHULUAN}

Karsinoma sel renal (KSR) merupakan kanker yang cukup sering terjadi, sekitar 3 sampai 4\% kasus di Amerika Serikat, namun di Asia kasusnya cukup jarang. Insiden KSR semakin menigkat dalam beberapa tahun terakhir. Perokok aktif dan pasif seperti juga hipertensi merupakan faktor risiko KSR. KSR juga sering terjadi pada pasien dengan obesitas, end-stage renal failure, acquired renal cystic disease, dan tuberous sclerosis. ${ }^{1,2}$

Sekitar 50\% kasus KSR ditemukan secara kebetulan dengan semakin berkembangnya pemeriksaan ultrasonografi, computed tomography (CT), dan magnetic resonance imaging
(MRI). ${ }^{2}$ Trias klasik dari KSR meliputi nyeri pinggang, gross hematuria, dan teraba masa di abdomen. Gejala metastase seperti nyeri tulang, nodul paru, sindrom paraneoplastik seperti hiperkalsemia, demam yang tidak dapat dijelaskan penyebabnya, eritositosis juga dapat dijumpai. ${ }^{3,4}$

KSR merupakan karsinoma traktus urinarius dengan angka mortalitas tertinggi dibandingkan keganasan lain pada organ tersebut. Sampai saat ini KSR masih menjadi masalah besar karena jenis tumor ini resisten terhadap kemoterapi maupun radioterapi. Banyak pasien yang tidak diketahui pada stadium awal dan baru terdeteksi pada stadium yang lanjut, 20-25\% bahkan terdiagnosis pada stadium IV atau sudah bermetastasis. ${ }^{3,5}$ 


\section{ILUSTRASI KASUS}

Pasien perempuan, 61 tahun, dikonsulkan oleh sejawat urologi dengan masa ginjal kanan suspect malignancy + CKD. Pasien datang dengan keluhan buang air kecil bercampur darah sejak 1 minggu sebelum masuk rumah sakit. Pasien juga mengeluhkan nyeri pinggang kanan sejak 2 minggu yang bertambah berat sejak 2 hari. Badan lemas sejak 1 minggu. Nafsu makan dikatakan menurun sejak 2 bulan terakhir, penurunan berat badan dialami sejak 4 bulan terkhir sekitar $6 \mathrm{~kg}$. Demam sumer-sumer dalam 3 bulan terakhir, membaik bila diberi obat penurun panas, namun kemudian naik kembali. Pasien sempat mengalami buang air kecil yang seret dan nyeri kencing awalnya, namun sudah membaik saat dibawa ke Rumah Sakit. Produksi urine dikatakan masih dalam batas normal sekitar $1000 \mathrm{cc} /$ hari. Keluhan sesak, batuk, mual, dan muntah tidak ada. Riwayat buang air kecil bercampur darah dan adanya batu ginjal kanan diketahui pada bulan April 2016 sudah dilakukan operasi pengangkatan batu namun saat itu tidak diketahui adanya massa pada ginjal kanan. Pasien juga mengalami buang air kecil bercampur darah kembali pada bulan Juni 2016, dirawat selama 2 hari dan dipulangkan saat kondisinya membaik. Riwayat hipertensi sejak 5 tahun namun tidak teratur minum obat. Riwayat kencing manis disangkal. Riwayat keluarga dengan penyakit batu atau kelainan ginjal lainnya disangkal. Riwayat merokok disangkal, namun suami pasien seorang perokok aktif.

Pada pemeriksaan fisik dengan kesadaran E4V5M6, tekanan darah $150 / 90 \mathrm{mmHg}$, nadi $82 \mathrm{x} /$ menit, frekuensi pernapasan $20 \mathrm{x} /$ menit dan temperatur aksila $36,2^{\circ} \mathrm{C}$. Pada pemeriksaan fisik paru dan jantung tidak didapatkan kelainan. Pada pemeriksaan abdomen tidak didapatkan nyeri ketok Costo Vertebral Angle (CVA). Kedua tungkai atas dan bawah hangat dan tak tampak oedema. Pada foto thoraks cor dan pulmo dalam batas normal. Pada pemeriksaan BOF didapatkan dengan suspek batu staghorn kanan dan suspek batu ureter 1/3 distal. Pada pemeriksaan awal didapatkan WBC 21,7, Hb 8,15, PLT 243, BUN 62 mg/dL, SC 8,16 mg/dL Na 133, $\mathrm{K} 4,9$, albumin 3,8 , kalsium $8 \mathrm{mg} / \mathrm{dL}$, fosfor anorganik 4,9 $\mathrm{mg} / \mathrm{dL}$. Dari analisa gas darah didapatkan asidosis metabolik dengan $\mathrm{PH} 7,31, \mathrm{pCO} 235,1, \mathrm{pO} 2$ 135, BE -9,2, HCO3- 17,10, $\mathrm{SO} 298$,4. Pada urinalisis terdapat proteinuria +4 , darah 250 , leukosit sedimen 3-5/lp, granula cast $(+)$.

Pemeriksaan USG Urologi pada Gambar 1 ditemukan ginjal kanan: ukuran normal, korteks tipis, batas sinus cortex tidak jelas, pelviocalyceal sistem melebar (grade IV), tampak batu multipel di pole atas, tengah, dan bawah ginjal kanan, tampak lesi hiperechoic batas tegas, ukuran sekitar 8,4-7,6 $\mathrm{cm}$ di pole atas ginjal kanan, dari ginjal kiri: ukuran normal, echocortex normal, batas sinus cortex jelas, pelviocalyceal sistem tidak melebar, tak tampak batu/ masa/ kista, dengan interpretasi masih tampak batu multipel di semua pole ginjal kanan dengan hidronefrosis grade IV, observasi lesi hiperechoic batas tegas, ukuran sekitar $8,4 \times 7,6 \mathrm{~cm}$ di pole atas ginjal kanan suspect massa dd/ hidronefrosis, ginjal kiri dan buli tak tampak kelainan.
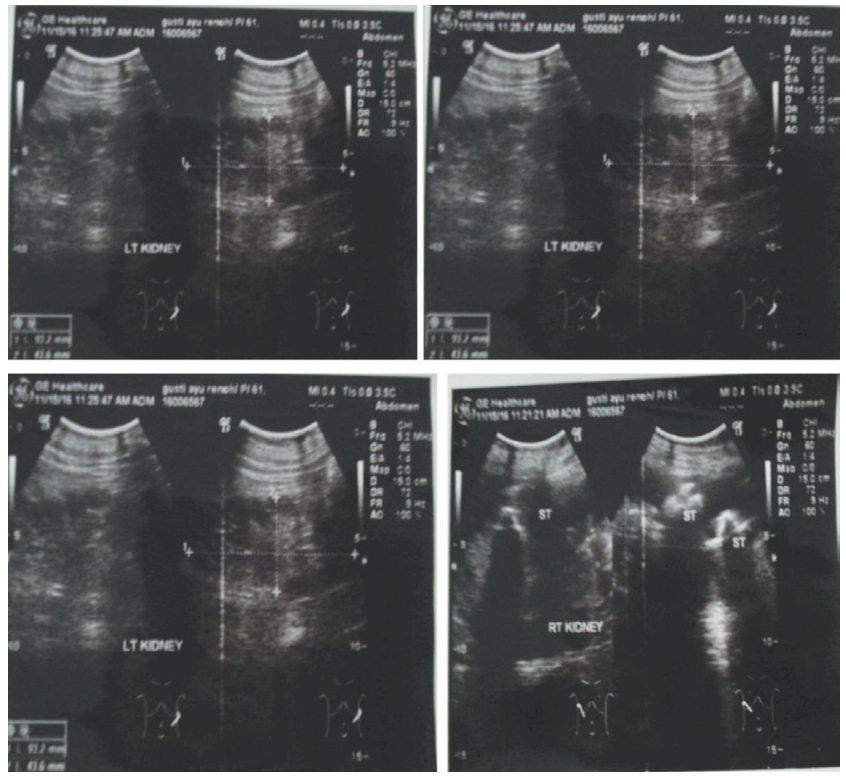

Gambar 1. USG Urologi

Pada pemeriksaan MSCT abdomen (Gambar 2) didapatkan kecurigaan massa pole atas sampai tengah ginjal kanan yang meluas ke jaringan lemak perirenal kanan dd/ abses ginjal kanan dengan perluasan ke perirenal kanan, batu staghorn ginjal kanan tanpa bendungan, batu ureter kiri $1 / 3$ distal yang menyebabkan hidronefrosis berat dan contracted ginjal kiri.
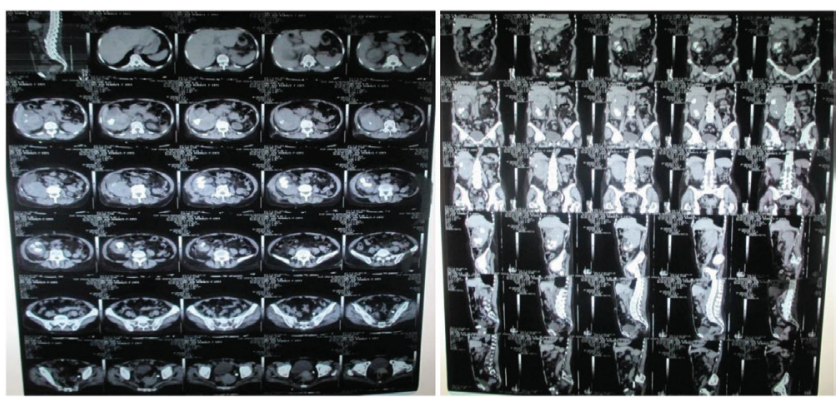

Gambar 2. MSCT abdomen

Pasien didiagnosis awal dengan ACKD ec post renal on CKD ec nefropati obstruktif, batu staghorn dan multiple ginjal dekstra, masa renal dekstra dd/ abses, hematuria, batu ureter $1 / 3$ distal sinistra, hidronefrosis grade IV ginjal sinistra, anemia ringan normokromik normositer on CKD, asidosis metabolik, hiperurisemia. Penanganan awal diberikan infus 
$\mathrm{NaCl}$ 0,9\% 20 tetes/menit, diet CKD $35 \mathrm{kkal} / \mathrm{kgBB} / \mathrm{hari}+$ protein $0,8 \mathrm{gram} / \mathrm{hari}$, alopurinol $1 \times 100 \mathrm{mg}$ io, asam folat $2 \times 2 \mathrm{mg}$ io, hemodialisis suportif, serta dilakukan monitoring fungsi ginjal dan produksi urine. Pada hari perawatan ke-20, dilakukan tindakan radical nefrectomy dekstra dan dilakuan pemeriksaan patologi anatomi (Gambar 3) dengan hasil adenocarsinoma (pT2), tidak tampak infiltrasi pada batas reseksi ureter, tampak metastase sel ganas pada 1 buah struktur KGB perirenal (pN1). Perkembangan selama perawatan kondisi klinis membaik nyeri pinggang berkurang dan urine tidak bercampur darah, dengan produksi urine 1000 cc/24 jam, didapatkan perbaikan fungsi ginjal BUN 88, SC 5,6. Pasien diadiagnosis akhir dengan CKD V et causa PNC single kidney, batu ureter $1 / 3$ distal sinistra, hidronefrosis grade IV ginjal sinistra, adenocarsinoma renal dextra stadium III post radical nefrectomy. Hari ke 30 perawatan pasien dipulangkan karena kondisi sudah membaik dan direncanakan hemodialisis reguler. Sepuluh hari post MRS pasien kembali dirawat dengan keluhan lemas, nafsu makan menurun, batuk disertai dahak warna kuning serta sesak nafas. Saat itu pasien dirawat dengan pneumonia (Health Care Associated Pneumonia) dan diberikan antibiotik empiris. Dalam perkembanganya kondisi pasien semakin memburuk dan akhirnya meninggal dengan penyebab kematian syok sepsis.
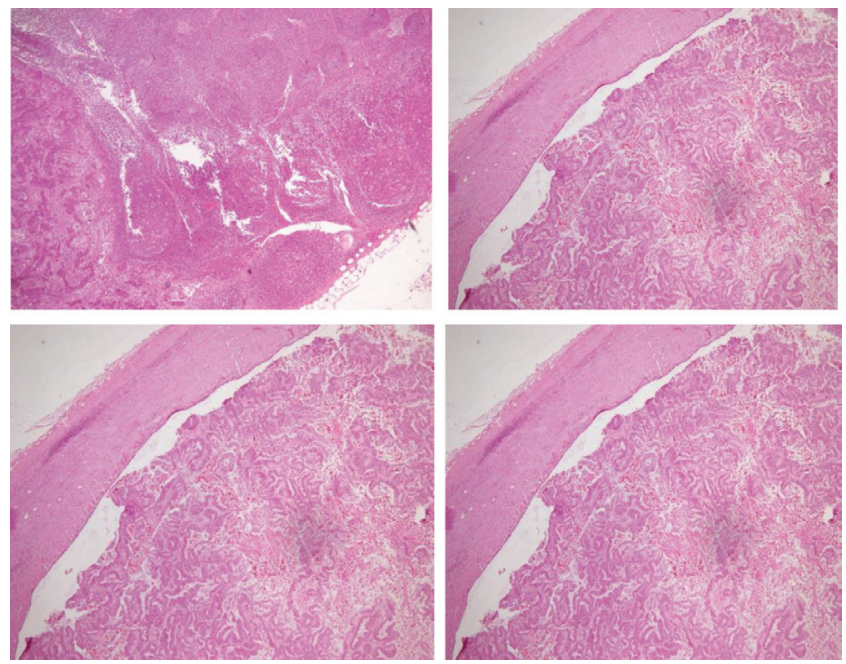

Gambar 3. Gambaran PA pasien menunjukan suatu adenokarsinoma renal Diskusi

Karsinoma sel renal atau adenokarsinoma ginjal berasal dari epitel tubulus proksimal dan merupakan 3\% dari keganasan pada orang dewasa dan biasanya ditemukan pada usia 50-70 tahun. Insiden KSR meningkat dalam 50 tahun terakhir di United States yaitu 9,1/100.000 populasi pada tahun 2007 dengan angka mortalitas 3,5/100.000 $(3,5)$. Insidennya dua sampai tiga kali lebih sering pada laki-laki dibandingkan perempuan. Penyebab pasti dari tumor ini belum diketahui walaupun secara eksperimen dilaporkan ada hubungan dengan cyscasin, aflatoxin, dan zat-zat kimia (timah dan cadmium), radiasi, virus, obesitas, diet tinggi protein dan hipertensi yang tidak terkontrol. Merokok merupakan faktor risiko tinggi. Tumor ini lebih sering didapatkan soliter, namun dapat juga multifokal (6-25\%), dengan kejadian bilateral KSR terjadi pada $4 \%$ kasus. ${ }^{4,6}$

Kondisi genetik tertentu berhubungan dengan terjadinya KSR, meliputi von Hippel-Lindau disease, hereditary papillary renal sel cancer, dan tuberous sclerosis. KSR terjadi pada $35-40 \%$ pasien von Hippel-Lindau Disease, terjadi pada usia muda, biasnya bilateral (75\%) atau multifokal. Hereditary papillary KSR bersifat autosomal dominan, yang lebih sering terjadi pada laki-laki dibandingkan perempuan 5:1.,7 KSR juga sering terjadi pada acquired cystic renal disease. Dialisis jangka panjang meningkatkan risiko 3 sampai 6 kali terkena KSR dibandingkan populasi normal. ${ }^{7,8}$ Pada kasus didapatkan pasien wanita dengan usia 61 tahun. Meskipun lebih sering terjadi pada laki-laki, namun adenokarsinoma juga dapat terjadi pada wanita. Faktor risiko yang didapatkan pada kasus ini diantaranya hipertensi yang tidak terkontrol dan pasien merupakan perokok pasif. Berdasarkan riwayat keluarga tidak diketahui adanya penyakit yang sama sebelumnya.

Manifestasi klinik KSR dapat asimptomatis, menunjukan gejala lokal yang tipikal, dan adanya manifestasi sistemik. KSR pada stadium awal sering tidak menimbulkan gejala. Sekitar 20-40\% karsinoma sel ginjal ditemukan pada saat pemeriksaan fisik rutin atau sebab lainnya. Pasien yang tidak menunjukan gejala apapun, sebagian besar termasuk dalam lesi stadium dini dan memiliki prognosis yang relatif baik. ${ }^{3,9}$ Trias gejala klinik klasik pada KSR meliputi nyeri pinggang, hematuria dan teraba adanya massa abdomen jarang ditemukan (6-10\%). Sekitar 40\% pasien KSR mengalami hematuria makroskopik yang intermiten dan pada sebagian kecil kasus terjadi hematuria mikroskopik. Hematuria masif dengan bekuan darah dapat menimbulkan kolik ginjal, sulit buang air kecil atau terasa nyeri, bahkan retensi urin., ${ }^{8,10}$ Bila ditemukan hematuria sebaiknya dievaluasi dengan pemeriksaan USG dan jika diperlukan dilanjutkan dengan pemeriksaan CT Scan pada pasien usia diatas 40 tahun. ${ }^{11}$ Ginjal terletak retperitoneal dan lokasinya dalam sehingga palpasi abdomen sulit merabanya, hanya jika tumor berukuran cukup besar atau terletak di kutub bawah ginjal, akan teraba adanya massa. Gejala klinis lain kadang tidak spesifik seperti demam yang tidak jelas penyebabnya, anemia, lesu, penurunan berat badan, hipertensi, gangguan fungsi hati (Stauffer syndrome), varikokel, dilatasi vena dinding abdomen, dan lain-lain. KSR sering di temukan pada stadium lanjut dan 25-30\% di temukan dengan metastasis $(5,10)$. Tumor dapat secara langsung menyebar melalui perinephric fat, kelenjar adrenal ipsilateral, dan dalam kasus yang lebih jarang melalui liver, spleen, dan kolon. Lokasi metastasis yang sering adalah di 
paru (50-60\%), kelenjar limfe (30-55\%), tulang (30-40\%), hati (20-40\%), kelenjar adrenal ginjal ipsilateral (20-25\%), kelenjar adrenal ginjal kontralateral (10-20\%), otak (5-8\%), jantung (5$6 \%)$, limpa (5\%), usus kecil (4\%) dan kulit (2-3\%). Pasien KSR dengan metastasis mempunyai prognosis sangat buruk. ${ }^{3,5}$

Pemeriksaan laboratorium yang dikerjakan pada kasus KSR seperti urinalisis, serum kreatinin, darah lengkap, laju endap darah, Laktat Dehidrogenase (LDH), fungsi hati, dan alkali fosfatase, Pada pemeriksaan urinalisis didapatkan hematuria. Namun perlu diingat bahwa tidak adanya hematuria tidaklah dapat menyingkirkan kemungkinan adanya tumor ganas ginjal. Pada pemeriksaan darah dapat dijumpai anemia, gangguan fungsi hepar, dan hiperkalsemia. Peningkatan laju endap darah juga sering dijumpai. ${ }^{4,8}$

Berdasarkan anamnesis pada kasus didapatkan keluhan urine bercampur darah, disertai nyeri pinggang kanan, pasien juga sempat mengeluhkan nyeri saat berkemih dan terasa seret. Demam sumer-sumer dialami pasien sejak kurang lebih 3 bulan disertai lemas dan nafsu makan yang menurun. Dari urinalisis didapatkan darah $(+250)$, pemeriksaan darah lengkap didapatkan anemia ringan dan dari kimia darah didapatkan peningkatan serum kreatinin.

Pemeriksaan pencitraan merupakan bagian penting dalam mendiagnosis KSR, termasuk didalamnya, pemeriksaan USG, CT dan MRI, sementara BNO-IVP dan angiografi ginjal sudah jarang digunakan saat ini. Skrining radioisotope terutama digunakan untuk menilai metastase tulang atau hati $(3,11)$. Pasien hematuria awalnya diperiksa dengan USG, jika menemukan kecurigaan suatu massa, dilanjutkan dengan pemeriksaan CT atau MRI untuk memperjelas diagnosis. Karsinoma asimtomatik sebagian terbesar terdeteksi dengan USG. Pemeriksaan USG umumnya dapat membedakan massa solid dan kista ginjal sederhana. Pada USG gambaran KSR tampak sebagai massa solid, tetapi dapat juga dijumpai sebagai lesi kistik pada 5-10\% kasus. Namun USG kurang sensitif dalam mendeteksi massa yang berukuran kecil Gambaran KSR pada pemeriksaan USG dapat hipoekoik, isoekoik, atau ekogenik relatif terhadap parenkim ginjal yang normal., ${ }^{512}$ Tumor memiliki kecenderungan untuk menyebar ke vena renal ipsilateral dan vena cava inferior sehingga perlu mengevaluasi adanya trombus pada vena tersebut. Trombus tumor akan tampak sebagai space-occupying mass. CT Scan kontras dapat mendiagnosis secara tepat sebagian besar kasus karsinoma ginjal, tapi kista hemoragik juga memiliki gambaran seperti karsinoma ginjal, dalam hal ini diperlukan pemeriksaan lanjutan berupa MRI untuk membantu membedakannya. Pada pemeriksaan CT Scan dapat ditemukan central scar tanpa penyangatan yang dikelilingi oleh penyangatan bentuk rim yang irregular. Tumor yang lebih besar cenderung memiliki batas tidak jelas antara tumor dan parenkim normal yang berdekatan. CT- Scan dan MRI sangat membantu dalam menemukan embolus vena dan stadium klinis. ${ }^{10,13}$ Modalitas lainya yang juga digunakan dalam diagnosis KSR adalah Contrast-enhanced ultrasonography (CEUs), dimana pemeriksaan ini lebih sensitif dibandingkan CT dalam pemeriksaan tumor hipovaskular. CEUs dikatakan memiliki spesifisitas 96,4\% dan sensitivitas $77,3 \%$ untuk mendeteksi KSR, pada massa ginjal yang berukuran kurang dari $5 \mathrm{~cm}$ yang sebagian besar lesi jinak. ${ }^{12}$

Pada kasus dari pemeriksaan USG didapatkan batu multipel di semua pole ginjal kanan, observasi lesi hiperechoic batas tegas, ukuran sekitar $8,4 \times 7,6 \mathrm{~cm}$ di pole atas ginjal kanan suspect massa dd/ hidronefrosis, ginjal kiri dan buli tak tampak kelainan. Dari pemeriksaan MSCT scan abdomen, didapatkan dengan kecurigaan massa di pole atas sampai tengah ginjal kanan yang meluas ke jaringan lemak perirenal kanan dd/ abses ginjal kanan dengan perluasan ke perirenal kanan, batu staghorn ginjal kanan tanpa bendungan, batu ureter kiri $1 / 3$ distal yang menyebabkan hidronefrosis berat dan contracted ginjal kiri. Sistem staging pada KSR digunakan untuk menetukan pilihan pengobatan, perencanaan bedah, menentukan prognosis, dan evaluasi penyakit. Sistem klasifikasi yang digunakan adalah sistem TNM dari American Joint Committee on Cancer (AJCC) dan International Union Against Cancer (UICC), 3,14,15

Klasifikasi stadium klinik ditambahkan huruf kecil c di depan stadium, misalnya cT2aNOM0. Sementara untuk penggolongan stadium patologik, ditambahkan huruf kecil "p" di depan stadium, misalnya pT2aNOM0. ${ }^{15,16}$

Pada kasus dari pemeriksaan PA didapatkan dengan hasil adenocarsinoma (pT2), tidak tampak infiltrasi pada batas reseksi ureter, tampak metastase sel ganas pada satu buah struktur KGB perirenal (pN1). Menunjukkan suatu kondisi adenokarsinoma renal stadium IIIB.

Pengobatan pilihan untuk tumor yang belum menunjukkan tanda-tanda metastasis adalah radikal nefrektomi. Radikal nefrektomi dilakukan jika ukuran tumor lebih dari $7 \mathrm{~cm}$, meliputi pengangkatan ginjal dengan fascianya, kelenjar adrenal yang berdekatan dan limfonodi regional. ${ }^{17,18}$ Pada tumor yang sudah bermetasasis jauh, nefrektomi radikal merupakan terapi paliatif bila ada hematuria, nyeri, atau sindrom paraneoplastik dan terapi sistemik lainnya tetap dibutuhkan. Meskipun tumor ginjal bersifat radioresisten, radioterapi dapat bermanfaat dalam menghilangkan metastasis jauh seperti di otak, tulang, dan paru. ${ }^{4,19}$

Surgical debulking tumor merupakan sebuah prosedur dimana sebuah tumor ganas diangkat secara parsial untuk kemudian mendapatkan terapi lanjutan berupa obatobatan, radiasi, atau lainnya sehingga dapat meningkatkan kelangsungan hidup. Debulking dianjurkan untuk penanganan beberapa jenis karsinoma seprti karsinoma testis, ovarium, subtipe limfoma, sarkoma, karsinoma sel ginjal, tumor adrenal 
dan lainnya yang terkait endokrin, neoplasma sistem saraf pusat, dan lain-lain. Debulking dikenal juga dengan sebutan cytoreductive surgery. ${ }^{5,18}$

Nefrektomi tumor bersifat kuratif, jika pembedahan yang dilakukan dapat mengeksisi semua massa tumor. Pada kebanyakan pasien dengan metastasis, cytoreductive nephrectomy merupakan terapi paliatif. Pada sebuah studi metaanalisis yang membandingkan antara cytoreductive nephrectomy dikombinasikan dengan imunoterapi dan imunoterapi saja, peningkatan angka harapan hidup ditemukan lebih tinggi pada pasien yang menjalani cytoreductive nephrectomy. ${ }^{18,20}$

Pada kasus telah dikerjakan radikal nefrektomi. Pasca operasi kondisi pasien sempat membaik, produksi urine cukup $\pm 800 \mathrm{cc} / 24$ jam, dan ada penurunan serum kreatinin. Pasien sempat menjalani beberapa kali hemodialis selama perawatan dan direncanakan hemodialisis regular. Sepuluh hari paska MRS pasien kembali dirawat dengan pneumonia (Health Care Associated Pneumonia) dan diberikan antibiotik empiris, dalam perkembanganya kondisi semakin memburuk dan akhirnya meninggal dengan syok sepsis.

Beberapa faktor dapat mempengaruhi prognosis penyakit ini seperti keadaan klinis, stadium, derajat histologi dan ukuran tumor. Secara umum presentasi harapan hidup untuk stadium I adalah 95\%, stadium II 88\%, stadium III 59\%, dan stadium IV 20\%. Paska dilakukan radikal nefrektomi karsinoma sel ginjal yang terlokalisir memiliki survival 5 tahun 89-94\%. Karsinoma sel ginjal yang terlokasisasi berdiameter $\leq$ $4 \mathrm{~cm}$, paska-operasi memiliki survival yang lebih tinggi yakni $90-100 \% .{ }^{19,21}$

\section{RINGKASAN}

Telah dilaporkan seorang pasien, perempuan 61 tahun dengan adenokarsinoma renal yang telah menjalani radical nefrectomy. Awalnya pasien menunjukan gejala urine bercampur darah, nyeri pinggang dan gejala sistemik lainnya seperti demam, lemas, serta penurunan nafsu makan. Gejala awal yang ditemukan sering tidak khas yang dapat mengaburkan diagnosis sehingga pasien baru diketahui menderita karsinoma renal pada stadium lanjut. Pemeriksaan penunjang seperti USG urologi dan CT Scan abdomen sangat membantu dalam penegakkan diagnosis. Penegakkan diagnosis pada stadium yang lebih dini akan mempengaruhi penanganan dan memperbaiki prognosis pasien.

\section{DAFTAR PUSTAKA}

1. Ljungberg B, Campbel SC, Cho HY, Jacqmin D, Lee JE, Weikert S. The Epidemiology of Karsinoma sel renal. Eur Association of Urology. 2011; 60: 615-21.

2. Jemal A, Siegel R, Ward E, Murray T, Xu J, Thun MJ. Cancer statistics 2007. Ca Cancer J Clin. 2007; 57:43-66.
3. Chaan S, Christopher W, Paul M, Nizar M, Pheroze T, Carl M. Karsinoma sel renal: Diagnosis, Staging, and Surveillance. AJR. 2008;191: 1220-1232.

4. Ljungberg B, Bensalah K, Bex A, Canfield S, Dabestani S, Hofmann F, et al. Guidelines on Karsinoma sel renal. Eur Association of Urology. 2013;1:28-37.

5. Escudier B, Eisen T, Porta J. Karsinoma sel renal: ESMO Clinical Practice Guidelines for Diagnosis, treatment, and follow up. Annals of Oncology .2012;1:vii65-vii71.

6. Clague J, Lin J, Cassidy A, Matin S, Tannir NM, Tamboli P. Family history and risk of Karsinoma sel renal: Results from a case-control study and systematic meta-analysis. Cancer Epidemiol Biomarkers Prev. 2009; 18:801-807.

7. Algaba F, Akaza H, Lo pez A. Current pathology keys of Karsinoma sel renal. Eur Urol. 2011;60:634-43.

8. Cohen HT, Francis J. Govern. Karsinoma sel renal. Medical Progress, NEJM 2005;353:2477-90.

9. Protzel C, Maruschke M, Hakenberg OW, Epidemiology, Aetiology, and Pathogenesis of Karsinoma sel renal. European Urology Suplement. 2012; 5: 52-9.

10. Godley P, Kim SW. Karsinoma sel renal. Curr Opin Oncol. 2002; 14:280285.

11. Dye R, Santis DJ, Clennan BL. Simplified Imaging Approach for Evaluation of Solid Renal Mass In Adult, Review for Resident, RadioGraphics 2008; 247 (2): 331-43.

12. Leveridge MJ, Bostrom PJ, Koulouris G, Finelli A, Lawrentschuk N. Imaging Karsinoma sel renal with ultrasonography, CT and MRI. Nat. Rev. Urol. 2010; 7: 311-25.

13. Wang JW. Imaging Findings of Common and Uncommon Karsinoma sel renals. JTUA. 2009; 20:10-14.

14. Choyke Pl, Newhouse JH, Bluth EI, . ACR appropriateness criteria: Karsinoma sel renal staging. American College of Radiology. 2002;2:43-66.

15. Edge, SB, et al. The American Joint Committee on Cancer : the $7^{\text {th }}$ edition of the AJCC cancer staging manual and the future of TNM. Ann Surg Oncol. 2010;1:1-12.

16. Hallscheidt PJ, Bock M, Riedasch G, Zuna I, Schoenbeg S, Autschach F, et al. Diagnostic accuracy of staging Karsinoma sel renals using multidetector-row computed tomography and magnetic resonance imaging: a prospective study with histopathologic correlation. J Comput Assist Tomogr. 2004; 28:333-339.

17. Sheth S, Scatarige JC, Horton KM, Corl FM, Fishman EK. Current concepts in the diagnosis and management of Karsinoma sel renal: role of multidetector CT and three-dimensional CT. RadioGraphics. 2001; 21:S237-S254.

18. Novick AC. Advances in the management of local- ized renal cell cancer. Can. J. Urol. 2000; 7:960-966.

19. Athar U, Gentile TC. Treatment options for metastatic Karsinoma sel renal: a review. Can. J. Urol. 2008;15:3954-66.

20. Saidi JA, Newhouse JH, Sawczuk IS. Radiologic follow-up of patients with $\mathrm{T} 1-3 \mathrm{a}, \mathrm{b}, \mathrm{c}$ or $\mathrm{T} 4 \mathrm{~N}+\mathrm{M} 0$ Karsinoma sel renal after radical nephrectomy.Urology. 1998; 52:1000-1003.

21. Ferlay J, Autier P, Boniol M, Heanue M, Colombet M, Boyle P. Estimates of the cancer incidence and mortality in Europe in 2006. Ann Oncol. 2007;18:581-92.

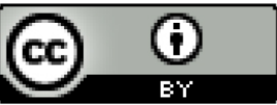

This work is licensed under a Creative Commons Attribution 4.0 International License. 